\title{
Ethanol Extract of Stylissa carteri Induces Cell Death in Parental and Paclitaxel-Resistant Cervical Cancer Cells
}

\author{
Isna Nisrina Hardani, ${ }^{1}$ Fachreza Aryo Damara, ${ }^{1}$ Annisa Dewi Nugrahani, ${ }^{1}$ Muhammad Hasan \\ Bashari $^{2,3}$ \\ ${ }^{1}$ Undergraduate Medical Program, Faculty of Medicine, Universitas Padjadjaran \\ ${ }^{2}$ Division of Pharmacology and Therapy, Department of Biomedical Sciences, Faculty of Medicine, Universitas \\ Padjadjaran \\ ${ }^{3}$ Oncology and Stem Cell Research Group, Faculty of Medicine, Universitas Padjadjaran
}

\begin{tabular}{|c|c|}
\hline \multirow[t]{3}{*}{ Abstract } & $\begin{array}{l}\text { Objective: To evaluate the cytotoxic effects of ethanol extract from marine } \\
\text { sponge Stylissa carteri in both parental and paclitaxel-resistant HeLa cervical } \\
\text { cancer cells. }\end{array}$ \\
\hline & $\begin{array}{l}\text { Methods: This was an experimental in-vitro study subjected ethanol extract } \\
\text { from Stylissa carteri obtained from Pramuka Island, Kepulauan Seribu } \\
\text { National Park, Jakarta. Both parental and paclitaxel-resistant HeLa cells were } \\
\text { treated with ethanol extract followed by microscopic observation and MTT } \\
\text { assay. The IC } \mathrm{I}_{50} \text { and drug curves were analyzed using four-parametric logistic } \\
\text { regression by SigmaPlot for Windows version } 12.0 \text { from Systat Software Inc., } \\
\text { USA. }\end{array}$ \\
\hline & $\begin{array}{l}\text { Results: Ethanol extract from Stylissa carteri triggered cell death-associated } \\
\text { morphological changes in parental Hela cells. It demonstrated cytotoxic } \\
\text { activities with an } \text { IC }_{50} \text { value of } 1 \text { ppm. Importantly, this extract also triggered } \\
\text { cell death in paclitaxel-resistant HeLa cells. The IC } \text { I }_{50} \text { of ethanol extract of } \\
\text { Stylissa carteri was } 4 \text { ppm in paclitaxel-resistant HeLa cells. }\end{array}$ \\
\hline $\begin{array}{l}\text { Received: } \\
\text { August 2, } 2018\end{array}$ & $\begin{array}{l}\text { Conclusions: There is a potential cytotoxic activity of Stylissa carteri that is } \\
\text { not only confirmed in parental HeLa cells but also in paclitaxel-resistant HeLa } \\
\text { cells. }\end{array}$ \\
\hline $\begin{array}{l}\text { Revised: } \\
\text { September 18, } 2018\end{array}$ & $\begin{array}{c}\text { Keywords: Cervical cancer, paclitaxel resistance, HeLa cells, cytotoxicity } \\
\text { assay, Stylissa carteri }\end{array}$ \\
\hline $\begin{array}{l}\text { Accepted: } \\
\text { September 19, } 2018\end{array}$ & $\begin{array}{l}\text { pISSN: 2302-1381; eISSN: 2338-4506; http://doi.org/10.15850/ijihs.v6n2.1378 } \\
\text { IJIHS. 2018;6(2):91-6 }\end{array}$ \\
\hline
\end{tabular}

\section{Introduction}

Despite the availability of advanced treatment options, cancers remain one of the major causes of mortality in the world after cardiovascular diseases. Data from World Health Organization (WHO), cancer was responsible for 8.8 million deaths in 2015. One of the deadliest cancers is cervical cancer. ${ }^{1}$ In Indonesia, cervical and breast cancers are cancers with the highest prevalence among women. Between 2005 and

Correspondence:

Muhammad Hasan Bashari, Division of Pharmacology and Therapy, Department of Biomedical Sciences,

Faculty of Medicine, Universitas Padjadjaran

Jl. Eyckman No.38 Bandung 40161, Indonesia e-mail: bashari@unpad.ac.id
2007, Jakarta Cancer registry has reported that the prevalence of cervical cancer in Jakarta is $9.25 / 100,000$ population. ${ }^{2}$ People's lifestyle, environmental changes, and possible genetic factors increase the risk for cervical cancer, creating a serious threat for women.

Several treatment options are available for cervical cancer including surgery, radiotherapy, chemotherapy, as well as their combination. ${ }^{3}$ The standard chemotherapy regimens used are the combination of cisplatin or paclitaxel therapy. ${ }^{3}$ Chemotherapy, as adjuvant therapy, plays an important role in preventing the recurrence and metastasis, thus increasing the life sustainability of cervical cancer patients. Unfortunately, some patients become 
resistant to chemotherapy drugs including to paclitaxel. In advanced cervical cancer, the overall response rate and the median overall survival are $29.1-67 \%$ and 12.87 months, respectively. ${ }^{4,5}$ Therefore, discovering a novel anticancer agent is very crucial.

Stylissa carteri, a marine sponge which is widely distributed in the Indonesian Exclusive Economic Zone (EEZ), has been recognized for its therapeutic potentials, especially for its anticancer properties. ${ }^{6}$ Based on our previous studies, ethanol extract of Stylissa carteri has been proven to induce cell death and to inhibit the cell proliferation of colon cancer cell lines as well as breast cancer cell lines (unpublished data). Hence, Stylissa carteri is thought to have a potential to target cervical cancer cells.

The anticancer property potential of marine sponge Stylissa carteri needs to be unravelled. Therefore, the analysis of cytotoxic activity of marine sponge extract and its potential toward paclitaxel resistance was conducted through the evaluation of cell death using MTT assay method in parental as well paclitaxel-resistant HeLa cervical cancer cells.

\section{Methods}

Subjects of this study were ethanol extract from Stylissa carteri gained from fresh sample collected in Pramuka Island, Kepulauan Seribu National Park, Jakarta, Indonesia. Stylissa carteri was collected and Identified by Beginner Subhan, M.Sc. from Bogor Agricultural University then extracted by Harold Atmaja.

This study was conducted on cervical cancer cell lines that included parental HeLa cells obtained from Ahmad Faried, dr., Sp.BS., Ph.D. (Dr. Hasan Sadikin General Hospital, Bandung, Indonesia) and paclitaxelresistant HeLa cells. The paclitaxel-resistant HeLa cells were generated by culturing parental HeLa cells with stepwise escalating concentration of paclitaxel (gifted by Pratiwi, Apt. from Pharmacy Dr. Hasan Sadikin General Hospital, Bandung, Indonesia) to have 3.5fold resistance which already represented clinically-relevant resistance. ${ }^{7}$ Both parental and paclitaxel-resistant HeLa cells were cultured in RPMI medium (cat No. 11875093, Gibco, USA) that was supplemented with $10 \%$ fetal bovine serum (FBS) (cat No. 10270106, Gibco, USA) and 1\% penicillin-streptomycin. Cells were incubated in an incubator with a controlled temperature at $37^{\circ} \mathrm{C}$ containing $5 \%$ $\mathrm{CO}_{2}$. The cells were sub-cultured until reaching $80-90 \%$ confluence.

Cytotoxic effects of the ethanol extract of Stylissa carteri in both HeLa cells was evaluated byusing the MTTassay (3-[4.5-dimethylthiazol2-yl]-2.5 diphenyl tetrazolium bromide, cat No. M2128, Sigma-Aldrich, USA), with a procedure as described in a previous study. ${ }^{8}$ The cells were seeded on 96-well plate then untreated or treated with sponge extract based on the indicated concentrations and then followed
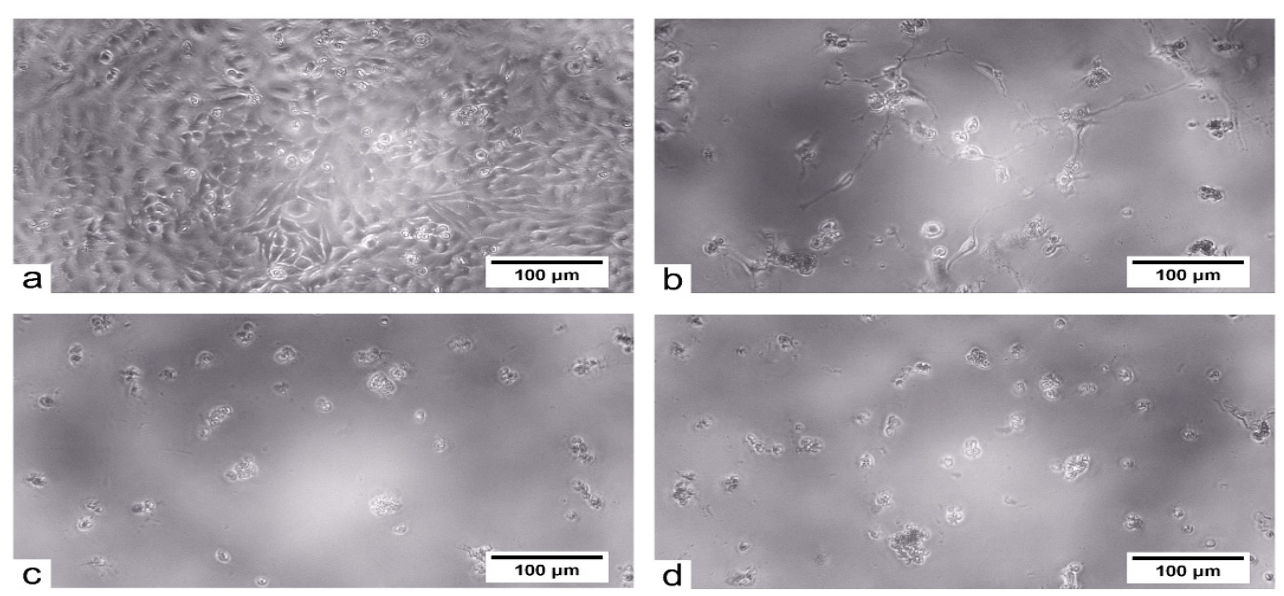

Fig. 1 Microscopic Appearance of Parental HeLa Cells of Untreated (Control) (a) and Treated with Ethanol Extract of Stylissa carteri with the Following Concentrations: 5 ppm (b), 50 ppm (c), and 100 ppm (d) (Magnification 100x) 
by incubation for 72 hours. Subsequently, cells were exposed to MTT reagent followed by stop reaction using dimethyl sulfoxide (DMSO, cat No. D8418, Sigma-Aldrich, USA). Then, the absorbance was measured using plate reader with $550 \mathrm{~nm}$ of wavelength. Cell death percentage was calculated by using sample's absorbance, control's absorbance, and also blank absorbance. The experiments had been triplicated. All procedures were conducted in the laboratory of cell culture and cytogenetic, Faculty of Medicine, Universitas Padjadjaran, Indonesia. The data was analyzed using fourparametric logistic regression by SigmaPlot for windows version 12.0 software from Systat Software Inc., USA. This study was supported by Program Kreativitas Mahasiswa (No. 141/ SPK/KM/IV/2018) from Kemenristekdikti for INH and Competence Research Grant from Universitas Padjadjaran for MHB (no.2476/ UN6.C/LT/2018).

\section{Results}

To evaluate the cytotoxic effects of the ethanol extract from Stylissa carteri, MTT assay was applied on parental and paclitaxel-resistant HeLa cells. The evaluation using MTT assay was started in the parental HeLa cells. Prior to the exposure to MTT reagent, we observed morphologic appearance of parental HeLa cells that were untreated and treated with ethanol extract of Stylissa carteri under microscope.

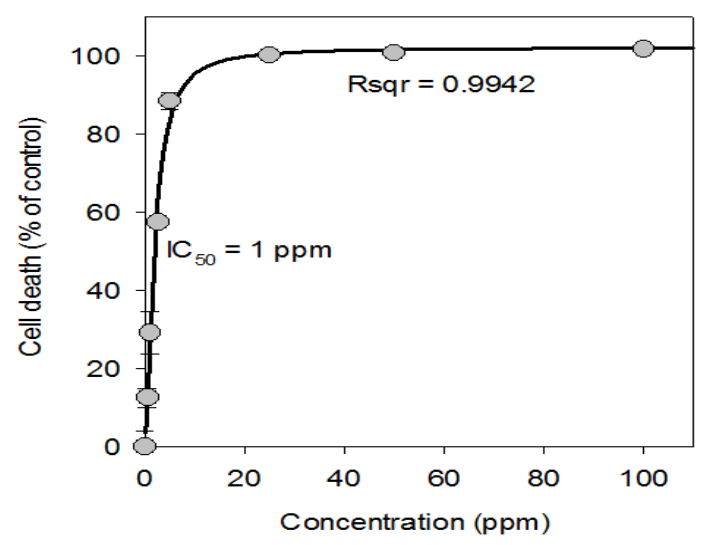

Fig. 2 Cell Death Curve Showing the Percentage of Parental HeLa Cell Death upon a Serial Concentration of Ethanol Extract of Stylissa carteri
Table Fold of Resistance of Paclitaxel in Paclitaxel-Resistant HeLa Cells

\begin{tabular}{cccc}
\hline IC & Parent & $\begin{array}{c}\text { Paclitaxel- } \\
\text { Resistant }\end{array}$ & $\begin{array}{c}\text { Fold of } \\
\text { Resistance }\end{array}$ \\
\cline { 2 - 3 } & \multicolumn{2}{c}{ Concentration (nM) } & \\
\hline 50 & 0.015 & 0.052 & 3.5 \\
75 & 0.061 & 2.011 & 33.0 \\
90 & 0.327 & 10.337 & 31.6 \\
\hline
\end{tabular}

Note: IC=inhibitory concentration

Data showed that an increasing of cell death-associated morphological changes along with the raising of concentration of the sponge extract (Fig. 1). Quantification of the cytotoxic effect was performed through measuring well absorbance and calculating the percentage of cell death after incubating the parental HeLa cells with MTT reagent for about 4 hours.

Data showed that the ethanol extract of Stylissa carteri induced cell death in parental HeLa cell line in a dose-dependent manner (Fig. 2). The $\mathrm{IC}_{50}$ of the ethanol extract from Stylissa carteri was achieved at $1 \mathrm{ppm}$ in the parental HeLa cells. The $\mathrm{IC}_{50}$ as well as the cell death curve were predicted and analyzed using four-parametric logistic regression with R square of 0.9942 .

Then, the cytotoxic effect of ethanol extract of Stylissa carteri in paclitaxel-resistant HeLa cells was evaluated. At first, the paclitaxel resistant Hela cells were less sensitive to

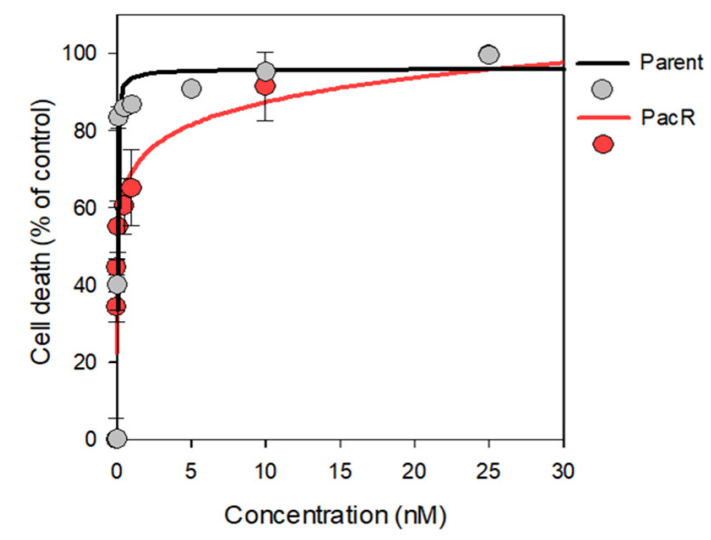

Fig. 3 Cell Death Curve of Paclitaxel Comparing the Parental and Paclitaxel-Resistant HeLa Cells 

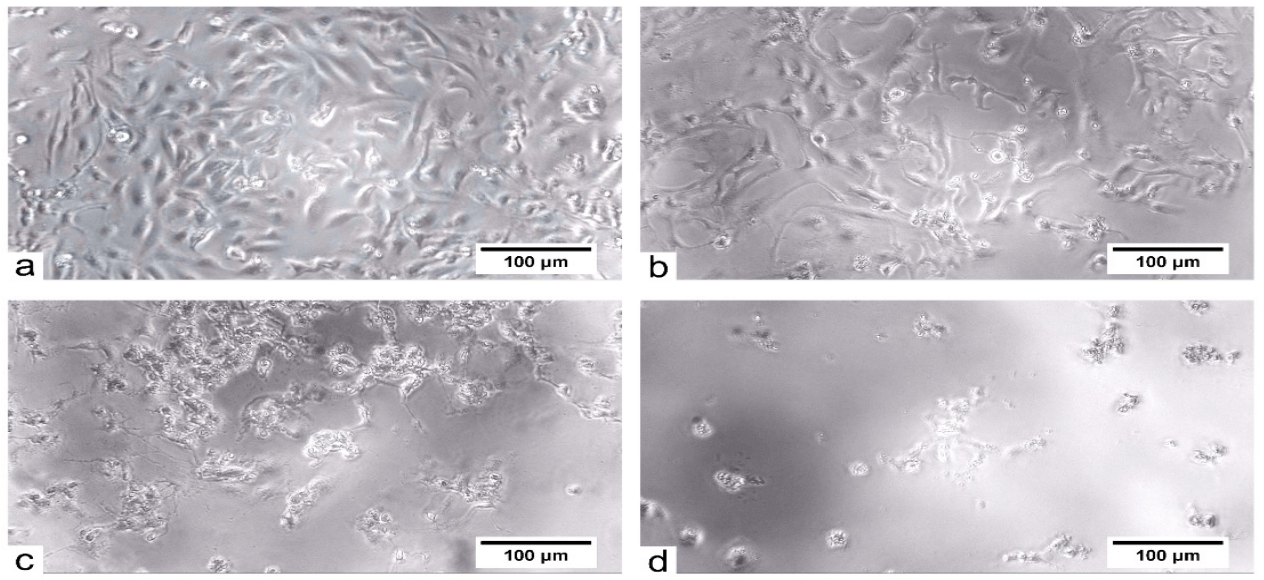

Fig. 4 Microscopic Appearance of Paclitaxel-Resistant HeLa Cells of Untreated (Control) (a) and Treated with Ethanol Extract of Stylissa carteri with the Following Concentrations: 5 ppm (b), 50 ppm (c), and 100 ppm (d). (Magnification 100x)

paclitaxel-induced cell death (Fig. 3) with 3.5fold resistance against paclitaxel compared to parental HeLa cells (Table).

Evaluation was continued with evaluating cell morphology of paclitaxel-resistant HeLa cells by inverted microscope upon treatment of ethanol extract of Stylissa carteri. Similar to the parental HeLa cells, the observation of paclitaxel-resistant HeLa cells also indicated the increasing of cell death along with the raising of concentration of the extract (Fig.4).

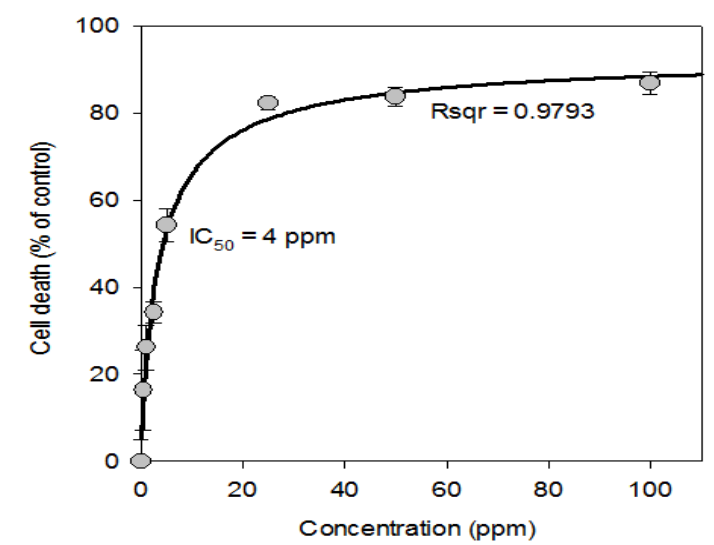

Fig. 5 Cell Death Curve Showing the Percentage of Paclitaxel-Resistant HeLa Cell Death against a Serial Concentration of Ethanol Extract of Stylissa carteri
The cytotoxic activity of the ethanol extract of Stylissa carteri was then evaluated using MTT assay. Interestingly, this extract was also triggered cell death in paclitaxel-resistant HeLa cells in a dose-dependent manner which $\mathrm{R}$ square was valued at 0.9793 (Fig. 5 ). The $\mathrm{IC}_{50}$ of ethanol extract of Stylissa carteri was $4 \mathrm{ppm}$ in paclitaxel-resistant HeLa cells.

\section{Discussion}

Stylissa carteri has become one of the well distributed sponges in Indonesian maritime. Moreover, it has known that Stylissa carteri was also found in Pacific's ocean overspread to Australia. Previous study had been conducted to evaluate the anticancer effects from Stylissa carteri collected from Indonesian marine sea. ${ }^{9}$ The study showed that the crude methanol extract of Stylissa carteri has cytotoxic effect in HeLa cervical cancer cell line with $\mathrm{IC}_{50}$ value 30 ppm. ${ }^{9}$ On the other hand, this study has proven that the $\mathrm{IC}_{50}$ value of ethanol extract of Stylissa carteri on parental HeLa cell was $1 \mathrm{ppm}$. A remarkable difference of $\mathrm{IC}_{50}$ value between the previous study and our study can be discovered. This different value is possibly resulted from different places of sponge collection. A previous study collected the sponges from Latondu Island, Sulawesi while this study collected the sponges from Pramuka Island, Kepulauan Seribu National 
Park, Jakarta. The different characteristics of water inhabits the sponge is causing chemical substantial difference due to the physiology of Stylissa carteri sponge that they are dependent on characteristic of water which constantly flow through their pores. Hence, the character of sponge's environment is very determining the quality of chemical compounds within Stylissa carteri extract. ${ }^{10}$

This study evaluated potential anti-cancer effects of Stylissa carteri on HeLa paclitaxelresistant cancer cell line. The results showed that the $\mathrm{IC}_{5}$ value in HeLa paclitaxel-resistant cancer cell line was $4 \mathrm{ppm}$. Therefore, Stylissa carteri sponge extract can significantly kill the paclitaxel-resistant HeLa cells. Stylissa carteri extract has very potential anticancer compounds that need to be furtherly evaluated. Moreover, data in this study showed the $\mathrm{IC}_{50}$ of ethanol extract of Stylissa carteri in both parental HeLa cells and paclitaxel-resistant HeLa cell lines were very low, indicating a strong cytotoxic activity.

Chemical screening and isolated compound evaluation of Stylissa carteri has shown that sponge extract contains a group of chemical compounds of cyclic peptides, alkaloid, and triterpenoid. The latest data from prior study has also shown towards the use of ethanol extract of Stylissa carteri also proved that is causing cell death and inhibition of cells proliferation and migration in both breast cancer and Caco-2 colon cancer cells (unpublished data). Among of those three groups of compound, cyclic peptides and alkaloid had proven that have anticancer effects and triterpenoid has anti-inflammation effects. ${ }^{9}$

\section{References}

1. Stewart BW, Wild CP. World cancer report 2014. Geneva: World Health Organization; 2014.

2. Wahidin M, Noviani R, Hermawan S, Andriani V, Ardian A, Djarir H. Population-based cancer registration in Indonesia. Asian Pacific J Cancer Prev. 2012;13(4):1709-10.

3. Marth C, Landoni F, Mahner S, McCormack M, Gonzalez-Martin A, Colombo N, et al. Cervical cancer: ESMO Clinical Practice Guidelines for diagnosis, treatment and follow-up. Ann Oncol. 2017;28(Suppl 4):iv72-83.

4. Zhu H, Luo H, Zhang W, Shen Z, Hu X, Zhu X. Molecular mechanisms of cisplatin resistance in cervical cancer. Drug Des Devel Ther [serial
The cyclic peptide compounds of Stylissa carteri have direct cytotoxic effect toward cancer cells as well as inhibiting angiogenesis. The cytotoxic effects of cyclic peptide was associated with pro-apoptotic proteins such as Bax, Bak, and BH3-only protein. ${ }^{11}$ Moreover, the inhibition of angiogenesis is resulted from cyclic peptide compounds through inhibition VEGF expression in cancer cells. ${ }^{12}$

In addition, alkaloid contained in sponge extract has significant role as the inhibitor of ubiquitin enzyme complex formation with proteasome that will p53 activity to lower the excessive cell proliferation activity in cancer cells and also cause apoptosis induction for proliferated cells. ${ }^{6,12}$

An evaluation of Stylissa carteri extract as their potential as anticancer agent has been conducted. Stylissa carteri ethanol extracts were treated toward parental HeLa cells and also paclitaxel-resistant HeLa cells. The study results revealed that Stylissa carteri extract induces cell death significantly among both of cell lines. However, this study was limited due to only using simple in vitro functional assay for cytotoxicity. Moreover, we also only used a crude ethanol extract of Stylissa carteri. A follow up study is conducting to further analyze the anticancer activity of Stylissa carteri not only by determining the molecular mechanism of Stylissa carteri against cancer cells but also isolating the bioactive compounds. In conclusions, this study indicates the potential of bioactive compounds from ethanol extract of Stylissa carteri to overcome cervical cancer, particularly in chemotherapy resistance. on the internet]. 2016 Jun [cited 2018 Apr 9];2016(10):[about 11p.]. Available from: https://www.ncbi.nlm.nih.gov/pmc/articles/ PMC4907638/.

5. Peng X, Gong F, Chen Y, Jiang Y, Liu J, Yu M, et al. Autophagy promotes paclitaxel resistance of cervical cancer cells: Involvement of Warburg effect activated hypoxia-induced factor 1- $\alpha$-mediated signaling. Cell Death Dis. [serial on the internet]. 2014 Aug [cited 2018 Apr 7];5(8):[about 11p.]. Available from: https:// www.nature.com/articles/cddis2014297.

6. O’Rourke A, Kremb S, Bader TM, Helfer M, Schmitt-Kopplin P, Gerwick WH, et al. Alkaloids 
from the sponge Stylissa carteri present prospective scaffolds for the inhibition of human immunodeficiency virus 1 (HIV-1). Mar Drugs. [serial on the internet]. 2016 Feb [cited 2018 Apr 9];102(6):[about 10p.]. Available from: http://www.mdpi.com/16603397/14/2/28.

7. McDermott M, Eustace AJ, Busschots S, Breen L, Crown J, Clynes M, et al. In vitro development of chemotherapy and targeted therapy drug-resistant cancer cell lines: a practical guide with case studies. Front Oncol [serial on the internet]. 2014 Mar [cited $2018 \mathrm{Apr}$ 9];4(40):[about 16p.]. Available from: 2https:// www.frontiersin.org/articles/10.3389/ fonc.2014.00040/full.

8. Bashari MH, Fan F, Vallet S, Sattler M, Arn $\mathrm{M}$, Luckner-Minden $\mathrm{C}$, et al. Mcl-1 confers protection of Her2-positive breast cancer cells to hypoxia: therapeutic implications. Breast Cancer Res [serial on the internet]. 2016 Mar [cited 2018 Apr 9];18(1):[about 15p.]. Available from: http://www.ncbi.nlm. nih.gov/pubmed/26921175\%5Cnhttp:/ / www.pubmedcentral.nih.gov/articlerender. fcgi?artid=PMC4769490.

9. Dewi AS, Suhita A. When East meets West: the chemistry of Indonesian sponges and Australian nudibranchs. [dissertation]. Queensland; The University of Queensland; 2017.

10. Lin Y-C, Tan F, Marra KG, Jan S-S, Liu D-C. Synthesis and characterization of collagen/ hyaluronan/chitosan composite sponges for potential biomedical applications. Acta Biomater. 2009;5(7):2591-600.

11. Boohaker RJ, Lee MW, Vishnubhotla P, Perez JM, Khaled AR. The use of therapeutic peptides to target and to kill cancer cells. Curr Med Chem. 2012;19(22):3794-804.

12. Afifi AH, El-Desoky AH, Kato H, Mangindaan REP, De Voogd NJ, Ammar NM, et al. Carteritins $A$ and $B$, cyclic heptapeptides from the marine sponge Stylissa carteri. Tetrahedron Lett. 2016;57(11):1285-8. 